Kajian Jurnalisme

ISSN 2549-0559 (cetak) ISSN 2549-1946 (online)

Volume 02 Nomor 01 Tahun 2018

\title{
Representasi Kekerasan Seksual Terhadap Perempuan Di Situs Berita Tirto.Id
}

\author{
Muji Rahayu dan Herlina Agustin \\ Program Studi Jurnalistik, Fakultas Ilmu Komunikasi, Universitas Padjadjaran \\ e-mail: mjrahayu124@gmail.com
}

\begin{abstract}
The purpose of this research is to understand how Tirto.id framed their news to represent the issues about sexual violence against women. This research used William A. Gamson and Andre Modigliani's Framing Analysis model. This type of model utilized framing devices in the form of analogy and parable (metaphors), interesting phrases and slogan (catchphrases), linking frame with examples and explanations (exemplars), picturing certain issues connotatively (depictions), and using pictures and graphics to support the frame (visual images). The reasoning devices utilized are causal analysis (roots), basic premises and moral claims (appeals to principle), and the effects of the frame (consequences). The result of this research showed that Tirto.id packed their news to represent sexual violence against women as a common enemy caused by patriarchy. This representation was served through the way they framed the ineffectivenes of Indonesian law enforcer in handling sexual violence cases, patriarchy's bad influences on the society and the men who perpetrate sexual violence, and also an education and call for action to the whole society to fight together in stopping sexual violence against women.
\end{abstract}

Keywords: Framing Analysis, Sexual Violence, Patriarchy, Representation.

\begin{abstract}
Abstrak
Penelitian ini bertujuan untuk mengetahui cara Tirto.id membingkai citra-citra tertentu untuk merepresentasikan kekerasan seksual terhadap perempuan. Metode yang digunakan adalah analisis pembingkaian (framing) model William A. Gamson dan Andre Modigliani. Model ini menggunakan perangkat pembingkaian berupa perumpamaan dan pengandaian (metaphors), frasa menarik dan kontras (catchphrase), pengaitan bingkai dengan contoh dan uraian (exemplars), penggambaran isu yang bersifat konotatif (depictions), dan penggunaan gambar dan grafik untuk mendukung bingkai (visual images), serta perangkat penalaran berupa analisis kausal sebab akibat (roots), premis dasar dan klaim moral (appeals to principle), dan efek atau konsekuensi bingkai (consequences).Hasil penelitian menunjukkan bahwa Tirto.id mengemas berita-berita ini untuk merepresentasikan kekerasan seksual terhadap perempuan sebagai musuh bersama akibat patriarki. Representasi ini ditunjukkan dengan pembingkaian ketidakefektifan penegakkan hukum di Indonesia dalam menangani kasus kekerasan seksual, pengaruh buruk patriarki kepada masyarakat dan kepada laki-laki pelaku kekerasan seksual, serta ajakan dan edukasi kepada masyarakat untuk berjuang bersama dalam menghentikan kekerasan seksual terhadap perempuan
\end{abstract}

Kata kunci: Analisis Framing, Kekerasan Seksual, Patriarki, Representasi

http://jurnal.unpad.ac.id/kajian-jurnalisme 
116 | Kajian Jurnalisme

ISSN 2549-0559 (cetak) ISSN 2549-1946 (online)

Volume 02 Nomor 01 Tahun 2018

\section{Pendahuluan}

Setiap tahunnya, masyarakat di seluruh dunia merayakan hari Perempuan Internasional dengan berbagai hal-hal tematik yang berhubungan dan mengedepankan kaum perempuan. Perayaan ini juga dilakukan oleh media-media di Indonesia, salah satunya adalah situs berita Tirto.id. Pada 8 Maret 2017, Tirto.id meluncurkan rangkaian berita spesial Hari Perempuan Internasional yang berisi 11 berita serta sebuah photo story yang berisi sekumpulan foto-foto aksi damai para perempuan di depan istana negara. Berbeda dengan situs-situs berita lain yang mengangkat isu-isu yang cenderung selebrasional, Tirto.id memanfaatkan momentum ini untuk meningkatkan kesadaran masyarakat terhadap isu-isu perempuan di Indonesia, salah satunya terkait kekerasan seksual terhadap perempuan dengan mendedikasikan tujuh berita dalam rangkaian ini untuk membahas isu tersebut.

Hari Perempuan Internasional sendiri merupakan perayaan mendunia yang sudah diakui oleh Perserikatan Bangsa-Bangsa. Berawal pada 1909 saat partai Sosialis Amerika mendedikasikan 8 Maret sebagai hari untuk memperingati protes yang dilakukan para perempuan pekerja garmen karena kondisi kerja yang buruk pada 1908. Seiring berjalannya waktu, setiap tahunnya Hari Perempuan Internasional selalu mengusung cita-cita emansipasi yang semakin meluas dan digunakan sebagai sarana untuk memperjuangkan hak-hak perempuan di berbagai belahan dunia (http://www.un.org/en/events/womensday/history.shtml, diakses pada Rabu, 8 November 2017, pukul $15.10 \mathrm{wib})$.

Pengangkatan isu kekerasan seksual terhadap perempuan oleh Tirto.id pada Hari Perempuan Internasional 2017 itu menjadi signifikan untuk digarisbawahi karena isu ini merupakan isu yang krusial di Indonesia. Hal ini berkaca pada laporan dari Catatan Tahunan Komnas Perempuan tahun 2017 yang memaparkan bahwa ada 259.150 kasus kekerasan terhadap perempuan dengan 3.495 kasus atau 34 persennya berupa kekerasan seksual. Selain itu, beberapa bulan sebelumnya, Indonesia sempat diguncang tragedi perkosaan massal dan pembunuhan tragis yang menimpa seorang anak di bawah umur berinisal YY di Bengkulu.

Komisi Nasional Anti Kekerasan Terhadap Perempuan mencatat bahwa ada 15 bentuk kekerasan seksual terhadap perempuan, yaitu perkosaan, intimidasi seksual termasuk ancaman atau percobaan perkosaan, pelecehan seksual, eksploitasi seksual, perdagangan perempuan untuk tujuan seksual, prostitusi paksa, perbudakan seksual, pemaksaan perkawinan (termasuk cerai gantung), pemaksaan kehamilan, pemaksaan aborsi, pemaksaan kontrasepsi dan sterilisasi, penyiksaan seksual, penghukuman tidak manusiawi dan bernuansa seksual, praktik tradisi bernuansa seksual yang membahayakan atau mendiskriminasi perempuan, dan kontrol seksual (www.komnasperempuan.go.id/reads-kekerasan-seksual-booklet, diakses pada Minggu, 5 November 2017, pukul 10.15 wib). 
Mengingat bentuknya yang sangat beragam, terkadang perempuan Indonesia gagal memahami bahwa yang terjadi pada mereka adalah salah satu bentuk kekerasan seksual. Terlebih, aparat penegak hukum di Indonesia belum bisa menerapkan pasal-pasal Kitab Undang-Undang Hukum Pidana (KUHP) yang membahas tentang kekerasan seksual terhadap perempuan yaitu pasal 285-290. Terhambatnya korban dalam memperjuangkan haknya adalah sebuah hal yang ironis, mengingat mereka yang seharusnya menegakkan keadilan justru masih memiliki perspektif patriarkis yang seringnya menyalahkan si korban. Hal ini tidak hanya membuat perempuan terdiskriminasi, tetapi juga menunjukkan ketidakpahaman pembuat kebijakan tentang akar permasalahan yang sebenarnya.

Seperti yang dituliskan Jurnal Perempuan:

"Kekerasan simbolis terjadi dalam bentuk representasi mengenai perempuan di ruang publik, sebuah norma yang mengatur bagaimana tubuh harus disajikan di dalam kehidupan sosial. Implikasi dari norma sosial yang menargetkan tubuh perempuan sebagai objek pengamatan masyarakat adalah pembenaran yang kian subur atas kekerasan yang menyasar pada tubuh perempuan. Logika ini pada akhirnya tidak sekadar sebuah struktur pikiran yang misoginis tetapi termanifestasi pula dalam praktis sosial. Seperti halnya begitu banyak aparat penegak hukum (APH), mulai dari polisi, jaksa, dan hakim yang mempraktikkan maskulin-normatif (norma laki-laki) di dalam proses penegakan hukum. Pola demikian akhirnya membuat pengalaman perempuan menjadi lemah di dalam sebuah proses hukum" (2016: 206).

Maka dari itu, ada dimensi lebih luas yang menyebabkan isu kekerasan seksual terhadap perempuan menjadi hal yang selalu signifikan untuk dibahas. Kebiasaan masyarakat yang cenderung selalu menyalahkan korban dan menutup mata pada pihak yang sesungguhnya bersalah adalah bentuk nyata dari langgengnya kekerasan seksual terhadap perempuan di Indonesia. Survei lembaga non-profit pendukung para penyintas kekerasan seksual, Lentera Sintas Indonesia pada 2016 menemukan bahwa 93\% penyintas pemerkosaan tidak pernah melaporkan kasus mereka ke aparat hukum. Hanya $1 \%$ penyintas yang memilih jalur hukum (www.magdalene.co/news-87193-persen-penyintas-tak-laporkan-pemerkosaan-yang-dialami-survei-.html, diakses pada Selasa, 06 November 2017, pukul 09:20 wib).

Salah satu penyebab dari belum berakhirnya kekerasan seksual terhadap perempuan di Indonesia adalah dianutnya budaya patriarki dalam masyarakat Indonesia. Patriarki sendiri dapat diartikan sebagai sistem pengelompokkan masyarakat sosial yang mementingkan garis keturunan laki-laki (Sastriyani, 2009:30). Dalam kehidupan masyarakat, paham patriarki berkembang menjadi sebuah cara untuk mendiskriminasi perempuan dengan menganggap perempuan sebagai pihak yang lebih inferior.

Sudut pandang yang menjunjung tinggi kuasa laki-laki itu sudah terlanjur dianut oleh sebagian besar masyarakat Indonesia. Akibatnya, banyak laki-laki yang bertingkah semena-mena dan perempuan yang tidak sadar akan pemenuhan hak-haknya. Ini diperparah dengan peran serta 
118 | Kajian Jurnalisme

ISSN 2549-0559 (cetak) ISSN 2549-1946 (online)

Volume 02 Nomor 01 Tahun 2018

media massa dalam menyampaikan pemberitaan terkait isu-isu kekerasan seksual terhadap perempuan. Alih-alih memakai kacamata Kode Etik Jurnalistik yang mewajibkan suatu produk jurnalistik agar selalu berimbang dan sesuai fakta sebenarnya, berita-berita ini justru mengandung bias gender dan sudut pandang victim blaming yang semakin memperburuk cara pandang masyarakat terhadap para korbannya. Pemberitaan tentang isu ini masih dipandang melalui stereotip gender yang cenderung merugikan perempuan, Sobur (2001:37) menyebutkan bahwa media massa terus menerus memproyeksikan peran-peran berdasarkan gender yang stereotip.

Berdasarkan paparan di atas, peneliti memutuskan untuk memilih Tirto.id dalam penelitian ini. Selain karena Tirto.id merupakan media berbasis data dan analisis media yang menggunakan sumber-sumber kredibel, Tirto.id juga memanfaatkan infografik-infografik menarik yang ikut memperjelas topik yang dibahas. Penggunaan infografik menurut peneliti sangat efektif untuk membuat pembaca tidak merasa bosan dan enggan saat membaca suatu topik yang dianggap "berat". Cara penulisan berita di media ini juga dibuat dengan gaya yang santai dan mudah dimengerti, sehingga pembaca tidak merasa digurui oleh istilah-istilah yang memusingkan.

Selain itu, umur Tirto.id masih tergolong muda, yaitu kurang dari 3 tahun karena mereka diresmikan pada 3 Agustus 2016 tidak menghalangi Tirto.id untuk menggunakan platformnya dalam menyuarakan isu-isu kekerasan seksual terhadap perempuan ini. Apalagi, rangkaian berita yang peneliti teliti diluncurkan sekitar tujuh bulan sejak Tirto.id berdiri. Sebuah langkah yang berani mengingat isinya tidak hanya sekadar memberitakan bahwa kekerasan seksual terhadap perempuan itu ada, tetapi juga merupakan tanggung jawab bersama masyarkat Indonesia.

Dengan pemberitaan ini, Tirto.id yang kala itu masih berstatus sebagai media baru tidak ragu untuk mengatakan bahwa para laki-laki yang menjadi pelaku kekerasan seksual adalah pihak yang sepatutnya disalahkan, serta pemerintah juga memiliki peran dalam menghalangi perempuan korban kekerasan dalam mencari keadilan dengan ketidakmampuan mereka menegakkan hukum yang berlaku. Hingga kini, hampir tiga tahun setelah diresmikan, konsistensi Tirto.id dalam mengangkat isu-isu kekerasan seksual terhadap perempuan tetap terjaga. Rangkaian berita ini seperti pintu pembuka bagi Tirto.id untuk mengukuhkan dirinya sebagai media yang memberitakan kekerasan seksual dengan kacamata gender. Karena itu, peneliti merasa bahwa meskipun rangkaian berita ini sudah lama dimuat, ia masih memiliki signifikansi tinggi untuk ditelaah dan diteliti.

Lebih jauh, Tirto.id juga mampu menempati posisi yang cukup populer di Indonesia walaupun masih berusia muda. Penghitung ranking situs internet Alexa mencatat, per Januari 2019 Tirto.id berada di posisi ke-52 sebagai situs yang sering diakses masyarakat Indonesia. Sementara itu, di posisi global, Tirto.id menempati urutan ke-2.105 (Tirto.id Traffic Statistics www.alexa.com/siteinfo/tirtoid, diakses pada Sabtu, 19 Januari 2019, pukul 22:30 wib). 
Kajian Jurnalisme

ISSN 2549-0559 (cetak) ISSN 2549-1946 (online)

Volume 02 Nomor 01 Tahun 2018

Alexa.com juga menunjukkan bahwa demografis pengunjung Tirto.id didominasi oleh lakilaki, sehingga pesan dan edukasi yang ingin disampaikan dalam rangkaian berita ini bisa langsung diterima oleh mereka yang selama ini menjadi mayoritas pelaku kekerasan seksual terhadap perempuan dan sebagai jenis kelamin yang mendominasi posisi-posisi yang berwenang membuat kebijakan dan menegakkan keadilan.

Who visits tirto.id?

Audience Demographics

How similar is this site's audience to the general internet population?

Gender

Male
Female
Education

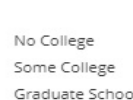

College
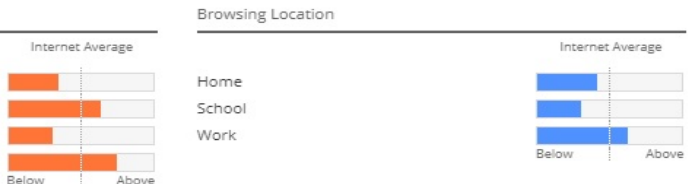

\section{Gambar 1. Demografis Pembaca Tirto.id per Januari 2019}

(Sumber: Alexa.com)

Ditambah lagi, lokasi akses serta tingkat pendidikan para pembaca juga sangat beragam, hal ini menunjukkan bahwa Tirto.id memiliki audiens yang heterogen. Keragaman ini membuat pesanpesan yang ingin Tirto.id sampaikan bisa menjangkau berbagai lapisan masyarakat Indonesia.

Hal tersebut membuat penulis semakin yakin untuk meneliti isu tentang kekerasan seksual terhadap perempuan yang dibahas dalam tujuh dari sebelas tulisan yang dimuat di Tirto.id dalam rangka Hari Perempuan Internasional itu. Mengingat, masih banyak para korban yang tidak mendapatkan keadilan yang semestinya karena hambatan aparat penegak hukum dan banyak juga yang malah justru menjadi korban dalam kasusnya sendiri dikarenakan budaya victim blaming yang ada di Indonesia.

\section{Metode}

Peneliti menggunakan metodologi kualitatif dengan paradigma konstruktivis, Hidayat (2002) memaparkan bahwa paradigma konstruktivis ini memandang ilmu sosial sebagai analisis sistematis terhadap socially meaningful action melalui pengamatan langsung dan rinci terhadap pelaku sosial dalam setting keseharian yang alamiah, agar mampu memahami dan menafsirkan bagaimana para pelaku sosial yang bersangkutan menciptakan dan memlihara atau mengelola dunia sosial mereka.

Pandangan konstruksionis juga memandang bahwa media media bukanlah sekadar saluran bebas, ia juga subyek yang mengkonstruksi realitas, lengkap dengan pandangan, bias, dan pemihakannya. Di sini media dipandang sebagai agen konstruksi sosial yang mendefinisikan realitas (Bennet dalam Eriyanto, 2002:26). 
120 | Kajian Jurnalisme

ISSN 2549-0559 (cetak) ISSN 2549-1946 (online)

Volume 02 Nomor 01 Tahun 2018

Selanjutnya, peneliti menggunakan analisis framing model William A. Gamson dan Andre Modigliani untuk melihat bagaimana Tirto.id membingkai rangkaian berita berisi isu kekerasan seksual terhadap perempuan ini. Model ini didefinisikan sebagai sebuah cara bercerita atau gugusan ide-ide yang terorganisir sedemikian rupa dan menghadirkan konstruksi makna peristiwaperistiwa yang berkaitan dengan objek suatu wacana. Cara bercerita itu terbentuk dalam sebuah kemasan (package). Kemasan itu semacam skema atau struktur pemahaman yang digunakan individu untuk mengkonstruksi makna pesan-pesan yang ia sampaikan, serta untuk menafsirkan makna pesan-pesan yang ia terima (Eriyanto, 2002: 77-70).

Untuk melihat cara Tirto.id mengemas berita-berita ini agar tidak menyalahkan perempuan dan menyudutkan korban, peneliti akan menggunakan perangkat-perangkat pembingkaian berdasarkan model ini, yaitu:

Tabel 1. Perangkat pembingkaian dan perangkat penalaran

\begin{tabular}{|l|l|}
\hline $\begin{array}{l}\text { Framing Devices } \\
\text { (Perangkat pembingkaian) }\end{array}$ & $\begin{array}{l}\text { Reasoning Devices } \\
\text { (Perangkat penalaran) }\end{array}$ \\
\hline $\begin{array}{l}\text { Methapors } \\
\text { Perumpamaan atau pengandaian }\end{array}$ & $\begin{array}{l}\text { Roots } \\
\text { Analisis kausal atau } \\
\text { sebab akibat }\end{array}$ \\
\hline $\begin{array}{l}\text { Catchphrases } \\
\text { Frase yang menarik, kontras, menonjol dalam suatu wacana. Ini } \\
\text { umumnya berupa jargon atau slogan. }\end{array}$ & $\begin{array}{l}\text { Appeals to Principle } \\
\text { Premis dasar, klaim- } \\
\text { klaim moral }\end{array}$ \\
\hline $\begin{array}{l}\text { Exemplar } \\
\text { Mengaitkan bingkai dengan contoh, uraian (bisa teori, } \\
\text { perbandingan) yang memperjelas bingkai }\end{array}$ & $\begin{array}{l}\text { Consequences } \\
\text { Efek atau konsekuensi } \\
\text { yang didapat dari } \\
\text { bingkai. }\end{array}$ \\
\hline $\begin{array}{l}\text { Depictions } \\
\text { Penggambaran atau pelukisan suatu isu yang bersifat konotatif. } \\
\text { Depiction ini umumnya berupa kosakata, leksikon untuk melabeli } \\
\text { sesuatu. }\end{array}$ & \\
\hline $\begin{array}{l}\text { Visual Images } \\
\text { Gambar, grafik, citra yang mendukung bingkai secara } \\
\text { keseluruhan. Bisa berupa foto, kartun, ataupun grafik untuk } \\
\text { menekankan dan mendukung pesan yang ingin disampaikan. }\end{array}$ & \\
\hline
\end{tabular}

Sumber: Eriyanto (2002: 262-263)

Gamson dan Modigliani juga mengungkapkan bahwa wacana media dapat dikonsepsikan sebagai seperangkat kemasan interpretif yang memberi makna pada suatu isu. Suatu kemasan 
Kajian Jurnalisme

ISSN 2549-0559 (cetak) ISSN 2549-1946 (online)

Volume 02 Nomor 01 Tahun 2018

memiliki struktur internal. Intinya adalah suatu gagasan yang mengorganisasikan, atau suatu kerangka (frame), untuk memahami peristiwa-peristiwa yang relevan, menyarankan apakah isu tersebut (Tuchman dalam Eriyanto: 2002).

Berdasarkan pemaparan tersebut, penulis memilih metode framing model Gamson dan Modigliani karena model ini tepat untuk mengupas seperti apa cara situs berita Tirto.id mengonstruksi dan merepresentasikan kekerasan seksual terhadap perempuan dalam Rangkaian Pemberitaan Hari Perempuan Internasional 2017. Selain menyorot bahasa sebagai aspek yang dianalisis, model ini juga menyentuh aspek-aspek lain seperti proses pendefinisian isu sebagai masalah sosial, tindakan kolektif dalam penyelesaian masalah tersebut, dan bentuk tindakan tersebut.

\section{Hasil dan Pembahasan}

Dari 11 berita yang ditampilkan Tirto.id dalam rangkaian pemberitaan Hari Perempuan Internasional 2017 ini, peneliti meneliti tujuh berita yang memiliki fokus bahasan mengenai kekerasan seksual terhadap perempuan. Berikut daftar berita yang diteliti:

Tabel 2

\section{Daftar Berita-Berita yang Akan Dianalisis}

\begin{tabular}{|l|l|l|l|}
\hline No. & Judul & Pranala & Keterangan \\
\hline 1 & $\begin{array}{l}\text { Melawan Stigma dan } \\
\text { Prasangka terhadap } \\
\text { Perempuan Indonesia }\end{array}$ & $\begin{array}{l}\text { www.Tirto.id/melawan-stigma-dan- } \\
\text { prasangka-terhadap-perempuan- } \\
\text { indonesia-ckko }\end{array}$ & $\begin{array}{l}\text { Dilengkapi } \\
\text { infografik dan foto }\end{array}$ \\
\hline 2. & $\begin{array}{l}\text { Mereka yang Dilecehkan } \\
\text { dan Mencoba Melawan }\end{array}$ & $\begin{array}{l}\text { www.Tirto.id/mereka-yang- } \\
\text { dilecehkan-dan-mencoba-melawan- } \\
\text { b9Vi }\end{array}$ & $\begin{array}{l}\text { Dilengkapi } \\
\text { infografik dan foto }\end{array}$ \\
\hline 3. & $\begin{array}{l}\text { Cara-cara Mematikan } \\
\text { Mempermalukan } \\
\text { Perempuan }\end{array}$ & $\begin{array}{l}\text { www.Tirto.id/cara-cara-mematikan- } \\
\text { mempermalukan-perempuan-b9ZV }\end{array}$ & $\begin{array}{l}\text { Dilengkapi } \\
\text { infografik dan foto }\end{array}$ \\
\hline 4. & $\begin{array}{l}\text { Kami Ingin Pria jadi } \\
\text { Solusi Menghapus Relasi } \\
\text { Patriarki }\end{array}$ & $\begin{array}{l}\text { www.Tirto.id/kami-ingin-pria-jadi- } \\
\text { solusi-menghapus-relasi-patriarki- } \\
\text { ckkp }\end{array}$ & $\begin{array}{l}\text { Dilengkapi } \\
\text { infografik dan foto }\end{array}$ \\
\hline 5. & $\begin{array}{l}\text { Hak Perempuan Diakui } \\
\text { sekaligus Diingkari }\end{array}$ & $\begin{array}{l}\text { www.Tirto.id/hak-perempuan-diakui- } \\
\text { sekaligus-diingkari-ckkA }\end{array}$ & $\begin{array}{l}\text { Dilengkapi ilustrasi } \\
\text { grafis }\end{array}$ \\
\hline 6. & $\begin{array}{l}\text { Wanita Indonesia dalam } \\
\text { Belenggu Kekerasan }\end{array}$ & $\begin{array}{l}\text { www.Tirto.id/wanita-indonesia- } \\
\text { dalam-belenggu-kekerasan-bB1H }\end{array}$ & $\begin{array}{l}\text { Dilengkapi } \\
\text { infografik dan foto }\end{array}$ \\
\hline 7. & $\begin{array}{l}\text { Dedi Mulyadi, } \\
\text { Catcalling, dan Ragam } \\
\text { Pelecehan Perempuan }\end{array}$ & $\begin{array}{l}\text { wwirto.id/dedi-mulyadi-catcalling- } \\
\text { b6cC }\end{array}$ & $\begin{array}{l}\text { Dilengkapi } \\
\text { infografik dan foto }\end{array}$ \\
\hline
\end{tabular}

http://jurnal.unpad.ac.id/kajian-jurnalisme 
122 | Kajian Jurnalisme

ISSN 2549-0559 (cetak) ISSN 2549-1946 (online)

Volume 02 Nomor 01 Tahun 2018

Sumber: Tirto.id dan olahan peneliti

\section{Penggunaan perumpamaan dan pengandaian (metaphors)}

Tirto.id menggunakan metaphors untuk mengungkapkan bahwa ada yang salah dalam penegakkan hukum Indonesia dalam kasus-kasus yang ada. Perumpamaan-perumpamaan itu seringnya dipakai untuk menggambarkan sebuah situasi sulit yang dihadapi para perempuan korban kekerasan seksual saat mencari keadilan dan bagaimana penegakkan hukum di Indonesia tidak mengakomodasi para korban yang berlindung kepadanya.

Beberapa metaphors dalam rangkaian ini yang menjelaskan tidak efektifnya penegakkan hukum di Indonesia terdapat pada berita Melawan Stigma dan Prasangka terhadap Perempuan Indonesia di mana kata "tumpul" digunakan untuk mendeskripsikan instrumen hukum menunjukkan bahwa ia tidak berguna sebagaimana mestinya. Hukum yang seharusnya melindungi dan memberikan keadilan justru dilihat oleh narasumber tersebut semakin memojokkan perempuan.

Selanjutnya, dalam berita Hak Perempuan Diakui sekaligus Diingkari istilah "segunung" dan "tembok tinggi" digunakan untuk menunjukkan bahwa kasus-kasus kekerasan seksual terhadap perempuan sudah memiliki jumlah yang amat banyak dan hukum yang seharusnya menjadi sarana untuk menyelesaikannya justru tidak bekerja dengan baik karena terhalang oleh berbagai macam faktor. Terutama minimnya implementasi dari aparat hukum yang seharusnya menjadi pihak yang menegakkan hukum tersebut. Minimnya penegak hukum yang memiliki perspektif gender dan memihak korban sudah menjadi "lagu lama" yang sering ditemui para korban keekrasan seksual, terbukti dengan pertanyaan-pertanyaan memojokkan korban, tidak menanggapi korban secara serius, dan memberikan justifikasi-justifikasi kepada is pelaku. Dengan membingkai isu tersebut dengan cara demikian, Tirto.id berupaya memberikan gambaran kepada masyarakat bahwa ada yang salah dengan cara lembaga hukum Indonesia dalam memperlakukan perempuan yang mencari keadilan.

Perumpamaan "angin lalu” dalam berita Dedi Mulyadi, Catcalling, dan Ragam Pelecehan Perempuan menggambarkan ketidakseriusan masyarakat, pemerintah, dan aparat penegak hukum dalam menanggapi kasus pelecehan seksual. Menurut Kamus Besar Bahasa Indonesia (https://kbbi.web.id/angin, diakses pada Rabu, 2 Januari 2019 pukul 14.00 wib), angin lalu berarti sesuatu yang bersifat sementara, kabar yang belum pasti (hanya kata orang), sesuatu yang tidak perlu didengar (diperhatikan), sesuatu yang remeh. Dari definisi tersebut, peneliti melihat bahwa pelecehan seksual di jalanan adalah sesuatu yang masih dianggap remeh dan tidak signifikan oleh masyarakat Indonesia.

\section{Pembentukan dan pemanfaatan frase dan jargon menarik, kontras, dan menonjol (catchphrase)}


Kajian Jurnalisme

ISSN 2549-0559 (cetak) ISSN 2549-1946 (online)

Volume 02 Nomor 01 Tahun 2018

Tirto.id menggunakan jargon-jargon menarik dalam berita untuk membentuk gagasan tentang kekerasan seksual terhadap perempuan sebagai dampak dari sistem patriarki. Tirto.id juga mengajak laki-laki untuk secara langsung berpartisipasi dalam melawan kekerasan seksual terhadap perempuan. Beberapa catchphrases yang digunakan Tirto.id untuk menunjukkan hal tersebut terdapat dalam berita berjudul Mereka yang Dilecehkan dan Mencoba Melawan. Dalam berita tersebut terdapat kalimat "Laki-laki semestinya bisa menahan diri, bukan menyerah pada nafsunya" (Paragraf 16). Fakta bahwa pernyataan tersebut diucapkan oleh seorang laki-laki memiliki pengaruh yang besar dalam mempertegas bingkai bahwa patriarki lah yang menjadi penyebab utama kekerasan seksual. Selain itu, kepedulian laki-laki untuk berani mengatakan bahwa pihak mereka sendiri yang bersalah karena tidak menahan diri bisa membuat masyarakat sadar bahwa menyalahkan korban bukanlah reaksi yang tepat saat terjadi kekerasan seksual.

Selanjutnya, di berita "Kami Ingin Pria jadi Solusi Menghapus Relasi Patriarki”, kalimat "Kami percaya juga bahwa jika kesetaraan itu tercapai, akan memberikan kebahagiaan kepada laki-laki dan perempuan" (Paragraf 11) menunjukkan bahwa Tirto.id ingin memberitahu pembaca bahwa kesetaraan bukan berarti menyingkirkan peran laki-laki dan hanya menomorsatukan perempuan, tetapi menempatkan keduanya secara adil dan setara. Jika itu dicapai, niscaya yang datang adalah rasa bahagia. Dalam konteks memutus relasi patriarki, manfaat yang didapat akan sangat banyak, kekerasan seksual terhadap perempuan akan berkurang, representasi perempuan di berbagai bidang ekonomi akan semakin baik, pekerjaan domestik dapat diselesaikan secara bersama, stigma bahwa laki-laki tidak boleh menangis dapat dihapus, masyarakat yang saling menghormati dan mengargai bisa terwujud, dan berbagai hal lain yang sebelumnya tidak berjalan karena terhalang patriarki.

Frasa menarik, menonjol, bahkan ironis dalam berita Hak Perempuan Diakui sekaligus Diingkari yaitu "Belum lagi persoalan korban yang sulit mengakses hak dalam proses pengaduan maupun pelaporan, kriminalisasi korban, dan aparat hukum yang tidak sensitif korban lantaran pandangan yang patriarkis" (Paragraf 6) juga semakin memperkuat bingkai. Korban yang seharusnya dan selayaknya mendapatkan keadilan atas apa yang terjadi padanya justru mendapatkan berbagai kesulitan. Perspektif patriarkis yang masih dianut oleh mayoritas masyarakat Indonesia seringnya membuat aparat hukum dan masyarakat menyepelekan pengaduan dari korban dan malah balik mengkriminalisasikannya, Tirto.id berusaha mengajak pembaca menyadari bahwa perempuan korban kekerasan yang mencari keadilan patut diberi kemudahan, jangan dikriminalisasi, dan agar aparat hukum jangan memakai prasangka yang bias gender saat menanganinya.

Dalam berita Wanita Indonesia dalam Belenggu Kekerasan, kalimat "Saya justru heran. Apakah mereka [laki-laki] benar-benar tidak bisa menahan libido dan menata ulang perilaku mereka?" (Paragraf 38), secara eksplisit menanyakan pada laki-laki terkait kemampuan kontrol diri mereka. Ia memiliki efek yang sangat kuat, yaitu seperti sebuah tantangan agar laki-laki menjadi pribadi dengan kualitas diri lebih baik, menjadi manusia yang decent dan tidak bertingkah 
124 | Kajian Jurnalisme

ISSN 2549-0559 (cetak) ISSN 2549-1946 (online)

Volume 02 Nomor 01 Tahun 2018

hanya dengan mengikuti selangkangannya. Peneliti juga melihat bahwa keputusan Tirto.id untuk tetap mencantumkan pertanyaan di atas dan menaruhnya sebagai penutup tulisan, adalah sebuah punchline bagus yang bisa mempertegas citra bahwa laki-laki harus memperbaiki pola pikir dan tingkah laku mereka.

\section{Pengemasan fakta dalam berita dan pengaitan bingkai dengan contoh serta uraian yang memperjelas bingkai tersebut (exemplar)}

Tirto.id mengemas fakta dan memperjelas bingkai berita bahwa kekerasan seksual terhadap perempuan sebagai suatu fenomena akibat patriarki yang perlu untuk dilawan bersama. Tirto.id menggunakan bahasa yang mudah dimengerti pembaca serta dilengkapi dengan infografis.

Exemplars yang dalam kalimat "Konstruksi sosial yang dibangun sangat didominasi oleh laki-laki dan hal itu juga mempengaruhi pola pikir perempuan, khususnya perempuan generasi sebelumnya yang juga melakukan pembenaran dan mereproduksi hal tersebut,' katanya" yang berada di paragraf ke-10 berita Melawan Stigma dan Prasangka terhadap Perempuan Indonesia menunjukkan bahwa Tirto.id berusaha menelusuri akar penyebab stigma dan stereotip muncul dengan menampilkan pendapat narasumber yang langsung menjelaskannya. Di sini Tirto.id memberikan informasi pada pembaca bahwa pelabelan dan pemberian stigma juga dilanggengkan oleh para perempuan itu sendiri, yang dari generasi ke generasi turut membudayakan kebiasaan pelabelan yang salah. Jadi, semua anggota masyarakat memang perlu melakukan tindakan nyata untuk menghapus patriarki.

Selanjutnya, di berita Mereka yang Dilecehkan dan Mencoba Melawan paragraf ke-24, Tirto.id berusaha menjalankan perannya sebagai agen penyebar nilai yang menunjukkan pada pembaca bahwa sebuah upaya menghapus kekerasan terhadap perempuan bukan hanya urusan perempuan, tetapi membutuhkan bantuan dari semua orang. Fungsi utama dari exemplar yatu mengaitkan bingkai dengan contoh dan uraian yang memperjelas bingkai dapat dicapai oleh kalimat tersebut. Dengan mengangkat gerakan dari Komnas Perempuan yang mana adalah badan pemerintah, Tirto.id dapat membentuk citra positif bahwa perjuangan kolektif terhadap kekerasan seksual terhadap perempuan memang dibutuhkan.

Exemplar dalam berita “Kami Ingin Pria jadi Solusi Menghapus Relasi Patriarki” juga menunjukkan pentingnya peran laki-laki dalam menghapus patriarki. Ditunjukkan dengan kalimat “Aliansi Laki-laki Baru adalah organisasi yang berupaya mendorong peran serta laki-laki untuk peduli terhadap isu perempuan. Aliansi mempromosikan kesetaraan gender dan berusaha mengubah paradigma patriarki dalam masyarakat. Salah satu isu perempuan yang kerap didorong dan dibicarakan untuk dikawal adalah kekerasan seksual dan pentingnya pemahaman tentang isu gender" (Paragraf 3). Kalimat tersebut secara eksplisit menjelaskan bahwa isu kekerasan seksual terhadap perempuan dan isu-isu lain yang menyangkut persoalan perempuan, bukan semata-mata sesuatu yang hanya perlu diperjuangkan oleh perempuan saja. Sebab, hampir seluruh diskriminasi, pelecehan, maupun kekerasan seksual dilakukan oleh laki-laki. Uraian di atas menjadi contoh yang 
Kajian Jurnalisme

ISSN 2549-0559 (cetak) ISSN 2549-1946 (online)

Volume 02 Nomor 01 Tahun 2018

baik untuk mengajak pembaca semakin memahami korelasi antara budaya patriarki dan laki-laki, karena laki-laki adalah pihak yang paling banyak diuntungkan oleh sistem yang mengutamakan kaum mereka. Melalui ALB, Tirto.id menunjukkan sisi lain isu perempuan, yaitu perlunya peran serta laki-laki, dan peran serta tersebut perlu dimulai dengan langkah awal berbentuk edukasi.

Penggambaran isu dengan memakai kata, istilah, dan kalimat konotatif agar khalayak terarah ke citra tertentu (depictions)

Tirto.id mengarahkan khalayak untuk melihat patriarki sebagai hal buruk yang menjadi penyebab utama kekerasan seksual terhadap perempuan. Pada berita Melawan Stigma dan Prasangka terhadap Perempuan Indonesia, citra itu ditunjukkan dalam kalimat "Salah satu penyebab mengapa kejahatan seksual atau pelecehan verbal bisa terjadi adalah cara pandang laki-laki Indonesia terhadap perempuan" (paragraf 13). Cara pandang tersebut merupakan hasil dari budaya patriarki yang sering memandang perempuan hanya sebagai objek semata, bukan manusia sepenuhnya. Melalui kalimat tersebut, pembaca dapat melihat akibat langsung dari patriarki.

Selanjutnya, depictions juga terdapat di berita Mereka yang Dilecehkan dan Mencoba Melawan. Kalimat "Pelecehan verbal melalui gurauan seksis merupakan langkah awal pelecehan yang lebih besar. Syaldi menilai akar masalah baik pelecehan seksual maupun verbal adalah relasi kuasa yang timpang antara laki-laki dan perempuan, kurangnya pemahaman tentang masalah gender, dan edukasi tentang consent" (paragraf 19). Tirto.id berusaha memberikan konotasi negatif terhadap sesuatu yang seringnya dianggap lumrah oleh masyarakat Indonesia, yaitu gurauan seksis. Sebuah hal hasil budaya patriarki yang kadang dianggap lumrah dalam keseharian namun bisa berujung pada kekerasan seksual yang lebih besar, misalnya perkosaan.

Pemanfaatan gambar, grafik, dan citra yang mendukung bingkai secara keseluruhan (visual images)

Tirto.id memanfaatkan perangkat visual images untuk menunjukkan bahwa kekerasan seksual terhadap perempuan adalah tindak kriminal yang pelakunya didominasi oleh laki-laki dengan menggunakan infografis dan foto. Berikut visual images tersebut: 
126 | Kajian Jurnalisme

ISSN 2549-0559 (cetak) ISSN 2549-1946 (online)

Volume 02 Nomor 01 Tahun 2018

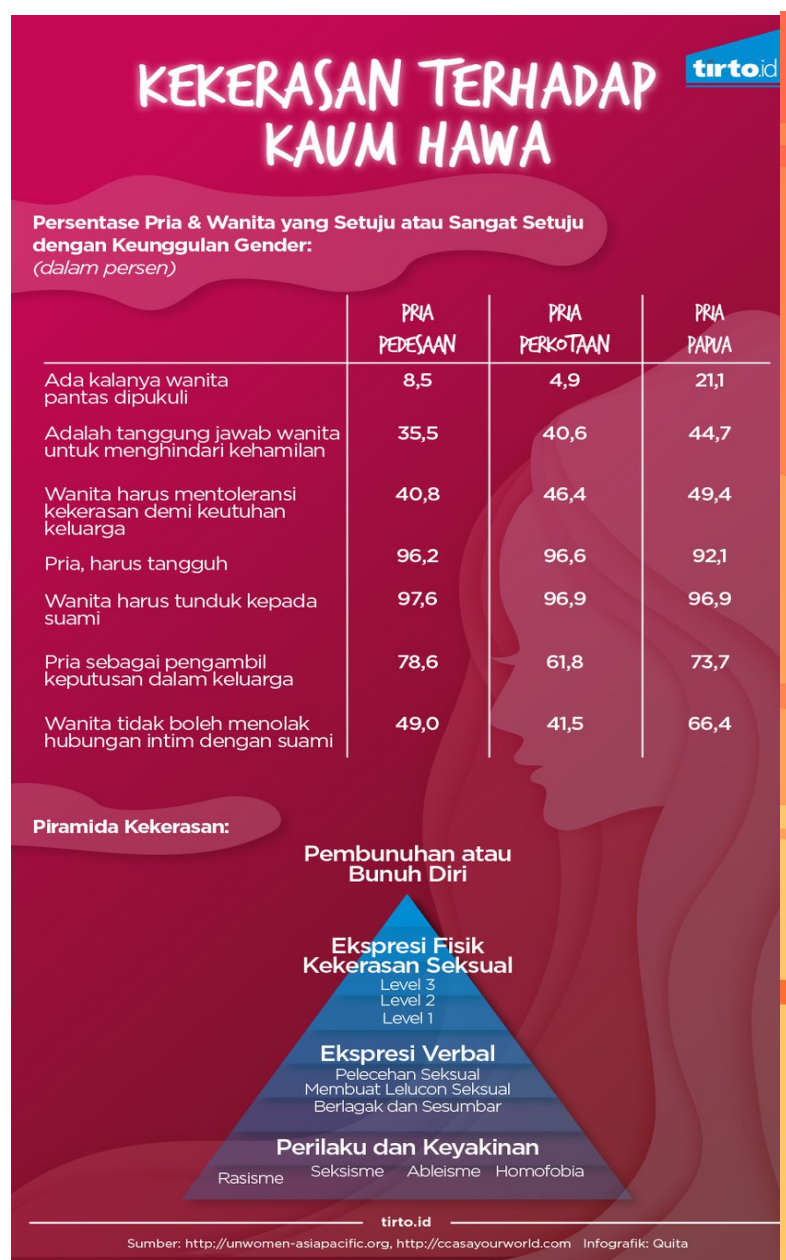

Gambar 2: Infografis dalam berita Mereka yang Dilecehkan dan Mencoba Melawan

(Sumber : Tirto.id)

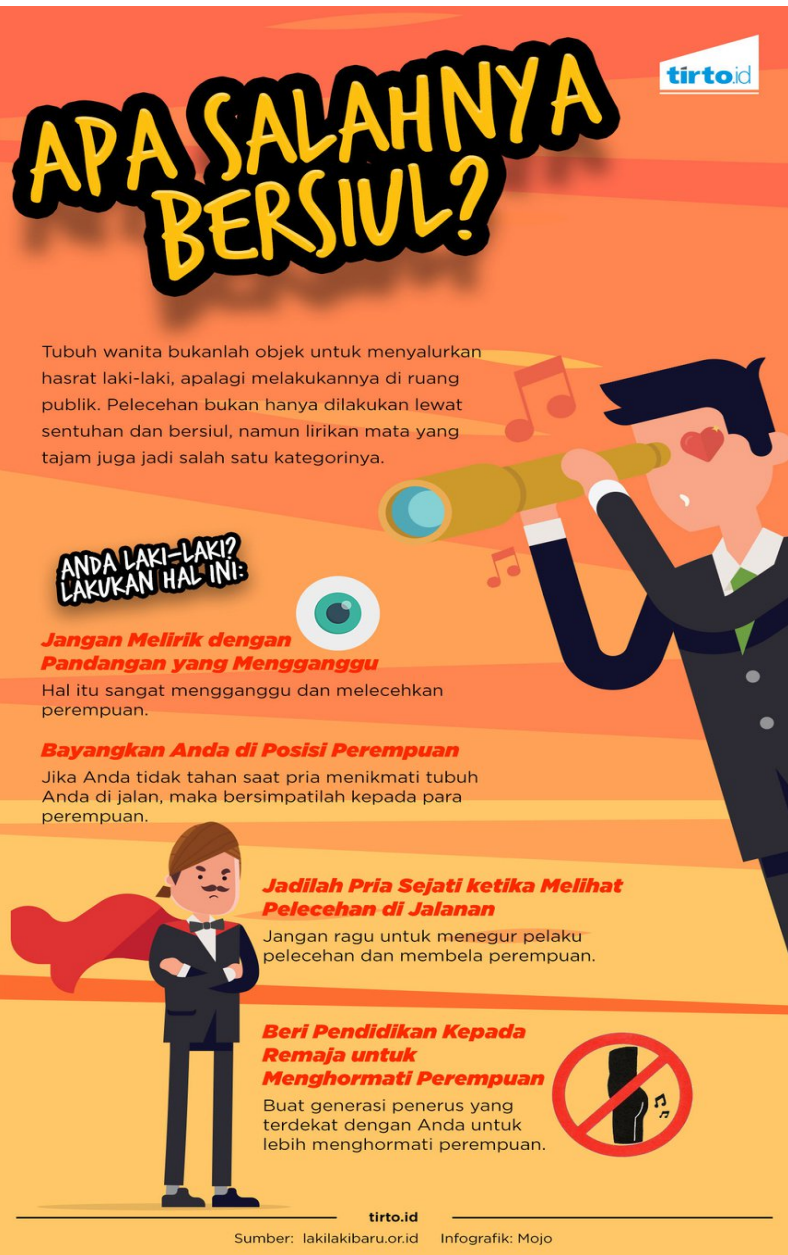

Gambar 3: Infografis dalam berita Cara-cara Mematikan Mempermalukan Perempuan

(Sumber: Tirto.id) 
Kajian Jurnalisme

ISSN 2549-0559 (cetak) ISSN 2549-1946 (online)

Volume 02 Nomor 01 Tahun 2018

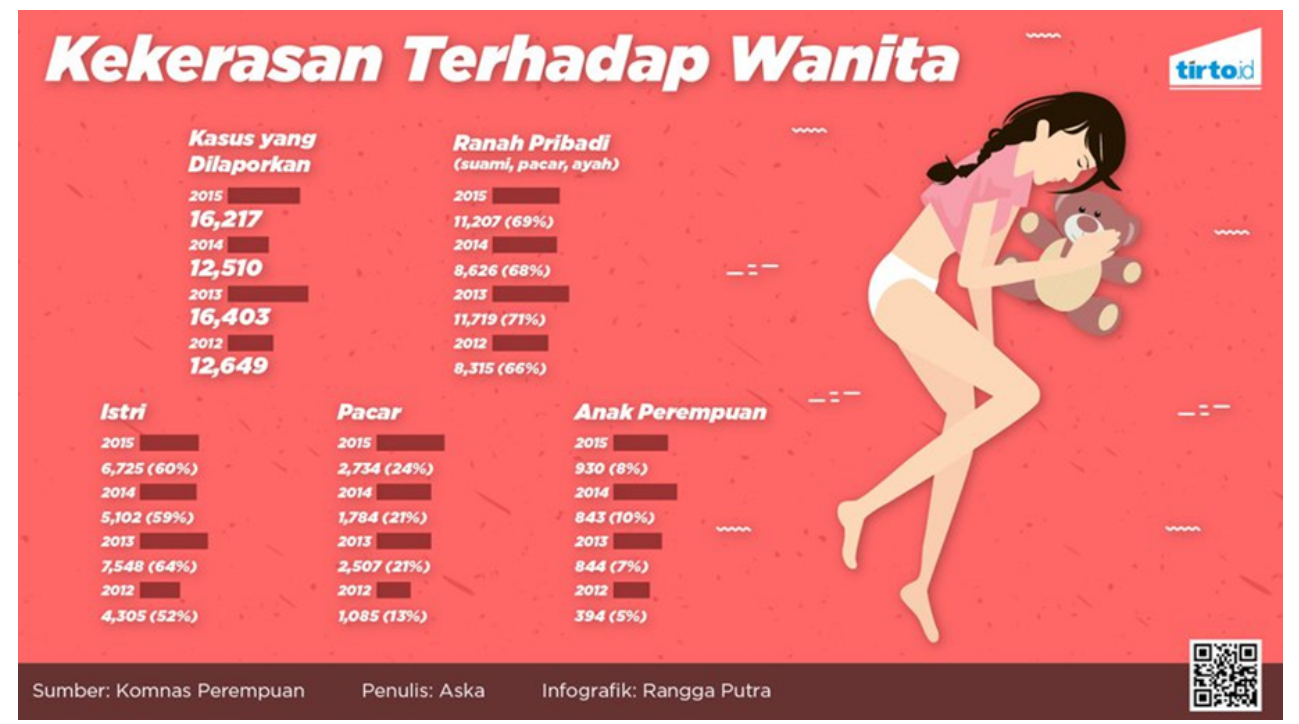

Gambar 4: Infografis dalam berita Wanita Indonesia dalam Belenggu Kekerasan

(Sumber: Tirto.id)

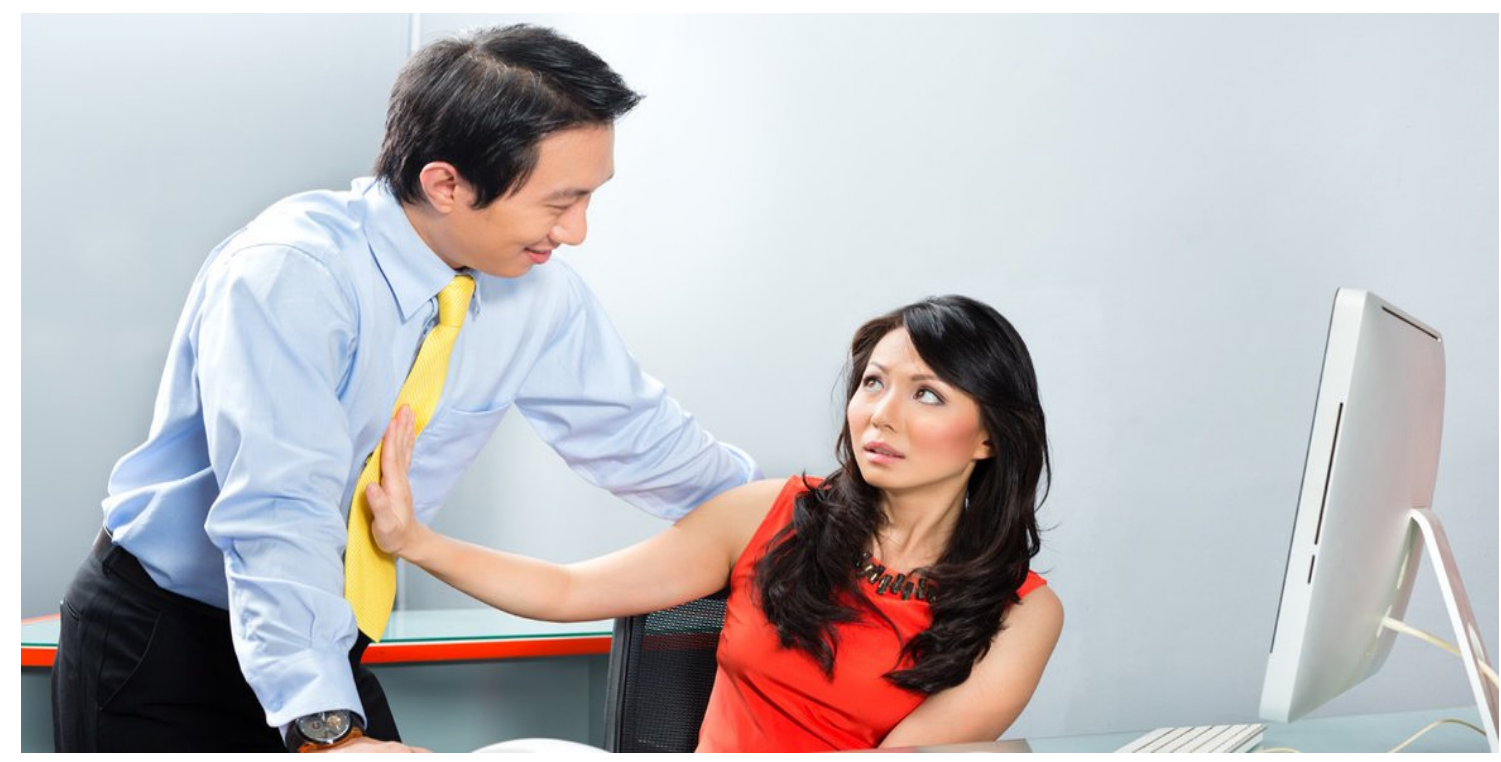

Gambar 5: Foto ilustrasi dalam berita Mereka yang Dilecehkan dan Mencoba Melawan (Sumber: Tirto.id)

Infografis berjudul "Kekerasan terhadap Wanita" berfungsi untuk mempertegas bingkai bahwa kekerasan terhadap perempuan di Indonesia sangat banyak terjadi. Sumber data yang digunakan adalah dari Komnas Perempuan, sehingga kredibilitasnya dapat dipertanggungjawabkan. 
128 | Kajian Jurnalisme

ISSN 2549-0559 (cetak) ISSN 2549-1946 (online)

Volume 02 Nomor 01 Tahun 2018

Selanjutnya, infografis "Kekerasan terhadap Kaum Hawa" memaparkan statistik dari UN Women tentang bagaimana para pria menyikapi kekerasan terhadap perempuan. Hasilnya cukup mengecewakan, yakni masih banyak pria yang menyetujui hal tersebut. Selain itu, data tentang piramida kekerasan yang menjelaskan tentang berbagai bentuk kekerasan juga ditampilkan. Menurut peneliti, infografik ini dapat membantu Tirto.id dalam merepresentasikan kekerasan seksual terhadap perempuan sebagai akibat patriarki melalui data dan fakta. Apalagi, sumber data yang menyebutkan bahwa masih banyak laki-laki yang mendukung kekerasan terhadap perempuan adalah Perserikatan Bangsa Bangsa; sebuah lembaga internasional yang sudah dipercayai kualitasnya. Tingginya persentase ini membuktikan bahwa pria masih memiliki pola pikir patriarki yang menganggap perempuan sebagai warga kelas dua, ini adalah fakta yang mendukung perlawanan bersama dari semua pihak untuk ikut bergerak.

Infografis berjudul "Apa Salahnya Bersiul” berisi tentang anjuran kepada laki-laki untuk tidak melakukan pelecehan verbal dan agar menjadi pihak yang membantu memberantas pelecehan. Data infografis tersebut bersumber dari situs organisasi lakilakibaru.org, sebuah organisasi laki-laki yang berkonsentrasi pada perjuangan kesetaraan gender dan hak-hak perempuan.

Foto dalam berita Mereka yang Dilecehkan dan Mencoba Melawan mengingatkan para pembaca laki-laki bahwa saat dirinya melakukan hal yang serupa dengan laki-laki dalam foto tersebut, itu merupakan tindakan yang tidak menyenangkan dan termasuk pelecehan.

\section{Teori Representasi}

1. Tirto.id mengonstruksi peristiwa kekerasan seksual sebagai realitas dengan memanfaatkan data-data hasil survei lembaga yang kredibel dan menyertakan penggalan teks dari suratkabar yang terkemuka di Indonesia, wawancara dengan berbagai pihak terkait, serta tujuan utama dari editor dan wartawan Tirto.id sendiri (Arman Dhani \& Maulida Sri Handayani, Wawancara, Jakarta 1 \& 7 Desember 2018), untuk mengonstruksi realitas tersebut sebagai sesuatu yang memang benar terjadi dan perlu untuk masyarakat ketahui.

2. Tirto.id menggambarkan realitas kekerasan seksual terhadap perempuan menggunakan perangkat-perangkat teknis seperti kata, proposisi, kalimat, foto, caption, dan grafik untuk menunjukkan bahwa ia adalah musuh bersama akibat patriarki.

3. Tirto.id mengorganisir peristiwa kekerasan seksual terhadap perempuan ke dalam konvensikonvensi yang diterima secara ideologis dengan melakukan upaya-upaya untuk mengedukasi masyarakat bahwa ideologi patriarki yang masih dianut oleh masyarakat Indonesia adalah sesuatu yang merugikan semua orang, baik laki-laki maupun perempuan. 
Kajian Jurnalisme

ISSN 2549-0559 (cetak) ISSN 2549-1946 (online)

Volume 02 Nomor 01 Tahun 2018

Berdasarkan tahapan-tahapan di atas, Tirto.id mengonstruksi, menggambarkan, dan mengorganisir peristiwa kekerasan seksual terhadap perempuan sebagai sebuah musuh bersama yang diakibatkan oleh sistem patriarki.

\section{Teori Konstruksi Sosial Media Massa}

1. Tahap persiapan materi konstruksi

Dalam tahap ini, Tirto.id harus mendistribusikan tugas-tugas pada desk yang ada. Menurut editor rangkaian berita ini yaitu Maulida Sri Handayani, di tahap ini isu yang dipilih biasanya berasal dari dua arah, dia bisa "memesan" isu tertentu kepada para wartawannya, atau para wartawan sendiri yang mengusulkan tema yang ingin mereka angkat (Maulida Sri Handayani editor Tirto.id, Wawancara, 7 Desember 2018). Untuk rangkaian berita ini, Maulida mengatakan bahwa para wartawan lah yang mengajukannya.

Selanjutnya, melalui wawancara dan analisis berita, peneliti juga menemukan fakta bahwa Tirto.id memiliki keberpihakan kepada masyarakat dan menganggap keuntungan yang didapat dari produk jurnalistik mereka sebagai sebuah efek samping dari apa yang mereka lakukan (Rahayu, 2019: 266).

2. Tahap sebaran konstruksi

Dalam menyebarkan konstruksi bahwa kekerasan seksual adalah musuh bersama akibat patriarki, Tirto.id memanfaatkan posisinya sebagai media daring yang memang memiliki karakteristik immediacy atau kecepatan penyampaian informasi (Ward: 2002).

3. Tahap pembentukan konstruksi

a. Dalam pembentukan konstruksi realitas, pertama Tirto.id memang melihat adanya fenomena kekerasan seksual terhadap perempuan yang semakin meningkat dari tahun ke tahun. Menurut Arman Dhani, data yang mendasarinya adalah catatan akhir tahun dari Komnas Perempuan yang menunjukkan bahwa angka kekerasan seksual terhadap perempuan semakin tinggi dan jenis-jenisnya juga semakin banyak (Arman Dhani, Wawancara, 1 Desember 2018).

Selanjutnya, dalam tahap kesediaan dikonstruksi oleh media massa, apa yang dilakukan Tirto.id merupakan konsekuensi yang didapat oleh pembaca sebagai pihak yang memang membaca Tirto.id sebagai sumber informasi secara sukarela.

Tahap terakhir yaitu konstruksi sebagai pilihan konsumtif. Di sini, Tirto.id berusaha memanfaatkan kebiasaan pembaca untuk mengonsumsi produk-produk jurnalistiknya sebagai jalan untuk mengubah pola pikir pembaca yang tadinya masih patriarkal, misoginis, dan tidak paham bahwa kekerasan seksual terhadap perempuan disebabkan oleh pelaku bisa diubah secara perlahan.

b. Dalam pembentukan konstruksi citra, Tirto.id menggunakan model bad news bahwa budaya patriarki adalah penyebab kekerasan seksual terhadap perempuan terus terjadi. 
130 | Kajian Jurnalisme ISSN 2549-0559 (cetak) ISSN 2549-1946 (online)

Volume 02 Nomor 01 Tahun 2018

Tirto.id selalu menambahkan kesaksian dan pengalaman pahit dari para penyintas untuk mengabarkan betapa buruknya kondisi kekerasan seksual terhadap perempuan di Indonesia.

\section{Tahap Konfirmasi}

Berdasarkan pernyataan-pernyataan dari editor maupun penulis rangkaian berita ini yang menyatakan bahwa mereka memang memiliki niat awal untuk berpihak pada perempuan korban kekerasan seksual dan membuktikan bahwa patriarki adalah musuh bersama (Arman Dhani dan Maulida Sri Handayani, Wawancara, 1 dan 7 Desember 2018), peneliti menyimpulkan bahwa Tirto.id memandang realitas sosial terkait kekerasan seksual terhadap perempuan dalam masyarakat kita sedang berada dalam titik yang mengkhawatirkan. Kekhawatiran dan keprihatinan tersebut akhirnya terakumulasi menjadi diturunkannya rangkaian berita yang mengupas seputar kekerasan seksual terhadap perempuan ini. Mulai dari sebab, budaya, kondisi masyarakat, hingga bagaimana menanganinya disajikan secara lengkap untuk mengubah pandangan masyarakat agar berhenti melanggengkan rape culture dan mulai menyadari akar masalah sebenarnya, yaitu patriarki.

Sementara itu, dari sisi pembaca, argumen yang dapat dijadikan alasan dalam tahap konfirmasi ini menurut peneliti adalah kesadaran kolektif sebagai anggota masyarakat yang selama ini ikut melanggengkan patriarki untuk mulai berbuat sesuatu. Menurut peneliti, fakta-fakta pahit yang disajikan dengan model bad news dalam rangkaian berita ini akan mampu menggugah pembaca untuk ikut terlibat langsung dalam pemberantasan patriarki. Terlebih, masing-masing berita ini selalu menyajikan klaim-klaim moral melalui kasuskasus menyayat hati yang mampu menggugah nurani masyarakat untuk ikut bergerak.

\section{Teori Kelompok Bungkam}

Dalam rangkaian berita ini, Tirto.id menunjukkan cara-cara perempuan melawan pembungkaman sebagai berikut:

1. Mengurutkan jenis-jenis teknik pembungkaman

Cara Tirto.id mengurutkan jenis-jenis teknik pembungkaman dalam rangkaian berita ini menurut peneliti cukup baik. Mereka, menyebar definisi, mengurutkan peristiwa, dan menyusun fakta-fakta teknik pembungkaman perempuan dalam tempat yang berbeda-beda, tidak menumpuknya dalam satu judul berita saja.

2. Menggunakan Kediaman

Dalam rangkaian berita ini, Tirto.id menunjukkan penggunaan metode kediaman sebagai strategi melawan pelaku pelecehan seksual saat si korban berada dalam posisi yang rentan (Rahayu, 2019: 282).

3. Merebut kembali, mengangkat, dan merayakan diskursus 'remeh' 
Kajian Jurnalisme

ISSN 2549-0559 (cetak) ISSN 2549-1946 (online)

Volume 02 Nomor 01 Tahun 2018

Tirto.id menerapkan cara perlawanan melalui diaries and journal ke dalam versi modern kedua hal tersebut, yaitu blog dan media sosial. Tirto.id menyajikan narasumber yang memanfaatkan hal tersebut untuk menyuarakan perjuangan mereka melawan kekerasan seksual.

4. Memberitahukan Kebenaran

Tirto.id menampilkan sosok-sosok perempuan yang berani menyampaikan kebenaran atas apa yang dia alami. Baik untuk meningkatkan kewaspadaan terkait kekerasan seksual terhadap perempuan, untuk meluruskan suatu hal yang selama ini tidak benar, maupun alasan-alasan lain yang menjadi dasar penceritaan tersebut.

5. Mengambil kontrol bahasa

Dalam rangkaian berita ini, Tirto.id menyajikan penggunaan-penggunaan istilah seperti "tubuhku otoritasku" untuk menunjukkan bahwa perempuan berhak untuk memiliki otonomi tubuh sendiri tanpa diatur dan ditindas oleh pihak-pihak eksternal dan mendefinisikan tindakan-tindakan pelecehan verbal sebagai sesuatu yang termasuk dalam kekerasan seksual.

6. Mengorganisir Kelompok Pendukung untuk Belajar Mempercayai Diri dan Kata-kata Kita sendiri.

Tirto.id menunjukkan aksi-aksi para perempuan yang melakukan perlawanan atas kekerasan seksual melalui aksi membuat video klip, membentuk organisasi perlawanan bernama Hollaback!, dan mengikuti aksi Women's March Jakarta.

7. Memulai media perempuan

Menurut peneliti, dalam konteks ini, perempuan tidak harus menciptakan sebuah media jurnalistik dari nol atau samasekali baru. Di sini, peneliti ingin menerapkan cara perlawanan ini pada fakta bahwa editor dari rangkaian berita ini serta beberapa penulisnya adalah seorang perempuan. Peneliti melihat, posisi-posisi tersebut sudah cukup memiliki kewenangan dalam menciptakan sebuah media jurnalistik yang ramah perempuan walaupun ada wartawan laki-laki yang ikut berkonstribusi.

\section{Simpulan}

Dilihat dari perangkat pembingkaian metaphors, Tirto.id menggunakan perumpamaan dan pengandaian untuk mengungkapkan bahwa ada yang salah dalam penegakkan hukum Indonesia dalam kasus-kasus yang ada. Tirto.id memanfaatkan perangkat metaphors dengan cara menggunakan berbagai perumpamaan yang menarik dan menohok. Perumpamaan-perumpamaan itu seringnya dipakai untuk menggambarkan sebuah situasi sulit yang dihadapi para perempuan korban kekerasan seksual saat mencari keadilan dan bagaimana penegakkan hukum di Indonesia tidak mengakomodasi para korban yang berlindung kepadanya. Penggunaan metaphors ini dapat 
132 | Kajian Jurnalisme

ISSN 2549-0559 (cetak) ISSN 2549-1946 (online)

Volume 02 Nomor 01 Tahun 2018

membantu pembaca untuk lebih memahami apa yang terjadi pada para korban dan bagaimana sebenarnya para aparatur negara ini memperlakukan para penyintas, mengingat sudut pandang korban merupakan poin penting dalam menyampaikan berita mengenai kekerasan seksual. Terlebih, berita-berita ini dikemas dengan menggunakan uraian yang mudah dimengerti namun tetap informatif.

Perangkat catchphrase diwujudkan oleh Tirto.id melalui jargon-jargon menarik yang berfungsi sebagai punchline dalam berita untuk membentuk gagasan tentang kekerasan seksual terhadap perempuan sebagai dampak dari sistem patriarki. Jargon-jargon ini dapat membuat pembaca terhenyak dan tersadar atas situasi kekerasan seksual terhadap perempuan di Indonesia. Bagi laki-laki, Tirto.id mengajak mereka untuk secara langsung berpartisipasi dalam melawan kekerasan seksual terhadap perempuan. Hal itu disampaikan dengan anjuran untuk melakukan intervensi jika melihat kekerasan seksual terjadi dan teguran untuk tidak lagi menjadi pelaku kekerasan seksual.

Dalam perangkat exemplar Tirto.id banyak menggunakan uraian-uraian yang bersumber dari para ahli, data statistik, serta literatur-literatur lain yang memiliki korelasi dan kredibilitas untuk mengemas fakta dan memperjelas bingkai bahwa kekerasan seksual terhadap perempuan merupakan suatu fenomena akibat patriarki yang perlu untuk dilawan bersama. Penjelasan yang ditampilkan mudah dimengerti karena dikemas dengan bahasa ringan dan dilengkapi dengan infografis menarik.

Melalui perangkat depictions Tirto.id menggambarkan patriarki sebagai sebuah sistem yang merugikan semua orang, tidak hanya perempuan. Ditambah lagi, citra patriarki sebagai akar dari kekerasan seksual dipaparkan dalam hasil riset, wawancara dengan para ahli dan narasumber yang terlibat langsung, serta bukti-bukti lain bahwa akibat buruk tersebut memang benar terjadi. Berdasarkan aspek tersebut, pembaca akan melihat dan memahami bahwa kekerasan seksual sebagai akibat dari sistem patriarki adalah sebuah tindakan yang salah dan melanggar hukum. Selanjutnya, kesadaran kolektif pembaca diharapkan dapat memicu tindakan yang dapat menurunkan tingkat kekerasan seksual terhadap perempuan di Indonesia.

Dalam visual images, Tirto.id merepresentasikan kekerasan seksual terhadap perempuan sebagai tindak kriminal yang pelakunya didominasi oleh laki-laki dengan menggunakan infografis-infografis "nyentrik" yang dibalut dengan humor. Meski dikemas secara ringan, esensi dari infografis tersebut tidak hilang. Sebab, informasi yang ditampilkan bersumber dari pihakpihak kredibel dan penggunaan perangkat visual ini merupakan alternatif lain bagi masyarakat yang enggan membaca teks berita dalam jumlah yang banyak.

Secara keseluruhan, Tirto.id merepresentasikan kekerasan seksual terhadap perempuan sebagai musuh bersama akibat sistem patriarki. Tirto.id menunjukkan bahwa kekerasan seksual terhadap perempuan merupakan isu sosial yang membutuhkan tindakan kolektif dari masyarakat. 
Kajian Jurnalisme

ISSN 2549-0559 (cetak) ISSN 2549-1946 (online)

Volume 02 Nomor 01 Tahun 2018

Ditilik dari teori-teori dalam penelitian ini, mereka juga telah berhasil membuat sebuah rangkaian berita yang berperspektif gender, tidak menyalahkan korban, memberi wadah bagi suara perempuan, dan bisa menjadi edukasi bagi seluruh lapisan masyarakat untuk turut serta dalam menghapuskannya.

\section{Daftar Pustaka}

Bungin, Burhan. (2011). Metodologi Penelitian Kualitatif. Jakarta: Kencana . . (2011). Sosiologi Komunikasi: Teori, Paradigma, dan Diskursus Teknologi Komunikasi di Masyarakat. Jakarta: Kencana.

Eriyanto. (2001). Analisis Wacana: Pengantar Analisis Teks Media. Yogyakarta: LKiS Yogyakarta.

. (2002). Analisis Framing: Konstruksi, Ideologi, dan Politik Media. Yogyakarta: LKiS Group.

Gamson, William A. \& Andre Modigliani. (1989). Media Discourse and Public Opinion on Nuclear Power, American Journal of Sociology, Vol. 95, No. 1. Diakses dari: http://www.jstor.org/stable/2780405?origin=JSTOR-pdf

Hidayat, Rahmad. (2004). Ilmu yang Seksis: Feminisme dan Perlawanan terhadap Teori Sosial Maskulin. Yogyakarta: Jendela.

Jurnal Perempuan. (2016). RUU Kekerasan Seksual. Jakarta: Yayasan Jurnal Perempuan.

Kramarae, Cheris \& Martha Houston (1991) "Speaking from Silence: Methods of Silencing of Resistance” Discourse and Society, 2, 387-399. Diakses dari: https://doi.org/10.1177/09579265.9100.2004001

Rahayu, Muji. 2019. Representasi Kekerasan Seksual terhadap Perempuan di Situs Berita Tirto.id: Analisis Framing William A. Gamson dan Andre Modigliani tentang Representasi Kekerasan Seksual Terhadap Perempuan dalam Pemberitaan Hari Perempuan Internasional 2017 oleh Situs Berita Tirto.id. Universitas Padjadjaran - Prodi Jurnalistik.

Sastriyani, Siti Hariti. (2009). Gender and Politics. Yogyakarta: Tiara Wacana.

Sobur, Alex. (2012). Analisis Teks Media: Suatu Pengantar untuk Analisis Wacana, Analisis Semiotik, dan Analisis Framing. Bandung: Remaja Rosdakarya.

Thacker, Lily K. (2017) "Rape Culture, Victim Blaming, and the Role of Media in the Criminal Justice System," Kentucky Journal of Undergraduate Scholarship: Vol. 1 : Iss. 1 , Article 8. Diakses dari: https://encompass.eku.edu/kjus/vol1/iss1/8

Ward, Mike. 2005. Journalism Online. London: Focal Press.

West, Richard \& Lynn H. Turner. 2008. Pengantar Teori Komunikasi: Analisis dan Aplikasi. Jakarta: Salemba Humanika.

\section{Sumber Internet:}

http://jurnal.unpad.ac.id/kajian-jurnalisme 
134 | Kajian Jurnalisme ISSN 2549-0559 (cetak) ISSN 2549-1946 (online)

Volume 02 Nomor 01 Tahun 2018

https://www.komnasperempuan.go.id/reads-kekerasan-seksual-booklet diakses pada Minggu, 5 November 2017, pukul 10.15 wib

http://www.magdalene.co/news-871-93-persen-penyintas-tak-laporkan-pemerkosaan-yangdialami-survei-.html, diakses pada Selasa, 06 November 2017, pukul 09.20 wib

http://www.un.org/en/events/womensday/history.shtml, diakses pada Rabu, 8 November 2017, pukul 15.10 wib

https://kbbi.web.id/angin diakses pada Rabu, 2 Januari 2019 pukul 14.00 wib

https://www.alexa.com/siteinfo/tirtoid, diakses pada Sabtu, 19 Januari 2019, pukul 22:30 wib

\section{Lain-lain:}

Kitab Undang-Undang Hukum Pidana

Undang-Undang Nomor 39 Tahun 1999 tentang Hak Asasi Manusia

Undang-Undang Nomor 23 tahun 2004 tentang Penghapusan Kekerasan dalam Rumah Tangga

Undang-Undang Nomor 12 Tahun 2005 Tentang Pengesahan International Covenant On Civil And Political Rights (Kovenan Internasional Tentang Hak-Hak Sipil Dan Politik)

Pedoman Pemantauan Terhadap Perempuan dalam Kerangka Hak Asasi Manusia oleh Komnas Perempuan (2011)

Laporan Catatan Tahunan Komnas Perempuan (2017) 